\title{
Human Communication with God through Asmaul Husna (99 Names of Allah) \\ (Study of Asmaul Husna's Understanding in Islamic Theology)
}

\author{
Muntasir $^{1}$, Saiful Bahri ${ }^{2}$, Yusfriadi ${ }^{2}$, Muttaqien $^{2}$, Ahmad Nidal $^{3}$, Fadlon $^{3}$ \\ ${ }^{1}$ Lecturer in UNIMAL Lhokseumawe, Aceh, Indonesia \\ ${ }^{2}$ Lecturer in Islamic Institute of Al-Aziziyah Samalanga, Bireun Aceh, Indonesia \\ ${ }^{3}$ Student in Islamic Institute of Al-Aziziyah Samalanga, Bireun Aceh, Indonesia \\ Email : muntasirakadir@yahoo.com
}

\begin{abstract}
:
One way to know God is by understanding the names of Allah (Asmaul Husna). Asmaul Husna is the mediator of communication used by Allah Almighty so that humans can confer to Him. This is what can be considered a channel through which humans can know God spontaneously. And it is precisely this which can move the way of discovery that is essential and opens up vast realms of spirituality to witness the light of Allah. The conclusions that can be drawn from the discussion of the understanding of Asmaul Husna in Islamic theology above are Asmaul Husna are the names of Allah that have been attributed by Allah to Himself, both those determined by Allah to Himself in Him in the Qur'an, and set by the Prophet without ta'wil (deviations), takyif (asking how), tamtsil (parable), and Tasybih (likeness). There is a difference of opinion among scholars in the determination of Asmaul Husna. The opinion of jumhur ulama that Asmaul Husna is limited by what has been determined by the Shariah. Ibn Qayyim's opinion that the determination of the attributes of perfection for Allah can be determined by what has been determined by the Shariah 'and with the five senses. Ibn Al-'Arabi views Asmaul Husna as an intermediary between God and nature, namely Asmaul Husna as the relationship between God and nature. Another view expressed by Ibn Qayyim in his book Madarijus Saalikin, that Asmaul Husna is a substance of God. This contradicts the opinion of some Mu'tazilah groups, that Asmaul Husna is a trait that is born. The opinion of the Jahmiyyah group that says Asmaul Husna is a being challenged by the Ahlus Sunnah group.

\section{Keywords :}

Al Quran; communication; Asmaul Husna; Allah
\end{abstract}

\section{Introduction}

Theological problem is the basis and foundation for the one religion that is embraced by humans, theology is the basis of every charity that humans do, and also determines human life, because discussion of theology, for example this Islamic theology leads to ma'rifah (knowing) God Swt. So by knowing God through Islamic theology whatever is done by humans will be directed to the right path.

One way to know God is by understanding the names of Allah (Asmaul Husna). Asmaul Husna is the intermediary used by Allah so that people can confer to Him. This is what can be considered a channel through which humans can know God spontaneously. And it is precisely this which can move the way of discovery that is essential and opens up vast realms of spirituality to witness the light of Allah.

Indeed, Allah has called Asmaul Husna for those who want to know it in the Qur'an and through the Prophetic traditions. But in understanding about the Asmaul Husna mentioned in the Qur'an and the hadiths arise various kinds of understanding about the problem of Asmaul Husna 
among Islamic theology experts. The emergence of various kinds of understanding of Asmaul Husna in Islamic theology is inseparable from the differences in the thinking of Islamic theology experts from the point of view and is inseparable from the different interpretations of the Naqli propositions which originate from the Qur'an and hadith. And also because the meanings that are attributed by God to Himself and those attributed by the prophet cannot be found true through their thoughts and observations.

This problem is very interesting and needs to be examined and discussed because this discussion is included in the discussion of Islamic theology, namely discussion that leads to the foundations or religious foundations embraced by humans in world life. So clearly this problem will later create a peaceful life among fellow humans, and get happiness in the world and the hereafter.

\section{Literature Review}

\subsection{Communication Concepts}

Communication has many definitions in accordance with the opinions of communication experts. Communication in learning in schools is an activity of transferring knowledge and skills from the teacher to students. This was confirmed by Everett M. Rogers, that communication is a process in which ideas are sent from the source to the recipient with the aim of changing their behavior. ${ }^{1}$ The definition says that the purpose of communication is to change behavior, in this context santri behavior is related to skills and science.

Edward Depari expressed his opinion, that communication is the delivery of ideas, hopes and messages conveyed through certain symbols, meaningful, carried out by the transmitter of messages addressed to the recipient of the message. ${ }^{2}$ While H.A.W Widjaja stated that communication is the delivery of information and understanding of someone to someone else. Communication can work well if mutual understanding arises, that is, if both the sender and the recipient of the information can understand. ${ }^{3}$ From some of these quotations it can be concluded that communication is the process of delivering information, whether in the form of messages, symbols, ideas or ideas carried out by the communicator or sender of the message to the communicant or recipient of the message.

In the learning process, a teacher is a communicator who conveys information in the form of learning material to students (communicants) who have a specific purpose and goal called the learning objectives. Therefore, communication will be effective and the purpose of communication will be achieved, if each of the actors involved in it has the same perception of information or symbols. Same thing in the learning process, communication will have a common perception of the learning objectives. That way the information transaction process in the form of learning material can be conveyed well from the teacher to the santri.

\footnotetext{
${ }^{1}$ Suranto A. W, Komunikasi Perkantoran: Prinsip Komunikasi untuk Meningkatkan Kinerja Perkantoran, (Yogyakarta: Media Wacana, 2005), p. 15

2 lbid, p. 15

${ }^{3}$ Widjaja. H. A. W, Komunikasi (Komunikasi dan Hubungan Masyarakat), (Jakarta: Bumi Aksara, 2002), p. 8 


\section{A. Elements of Communication}

From the definition of communication that has been described above, there are several elements that are prerequisites for a communication. The elements of communication according to H. A. W. Widjaja are as follows: ${ }^{4}$

1) Sources

Resources are the basis used in the context of delivering messages, which are used to strengthen the message itself. Sources can be people, institutions, books and the like.

2) Communicators

Communicators can be individuals who are talking, writing, groups of people, communication organizations such as radio, newspapers, and so on. In the reception and so forth.

3) Receiver

Receiver of messages can be classified into 3 types, namely personal, group and mass.

4) Message

The message is the whole of what is conveyed by the communicator. The message should have the core message (theme) as a command in an attempt to change the communicant's attitudes and behavior.

5) Channels or Media

The communication channel always conveys messages that can be received through the five senses or using the media.

6) Results

Effect is the end result of a communication, namely attitudes and behavior of people, according to or not with what we want. So if the attitude or behavior of others is in accordance with our desires, it means that communication can be said to succeed and vice versa.

From the communication elements above, it can be said that the communication process is carried out by the communicant and the communicator, the communicator conveys a message or desire to the communicant that influences the communicant so that the communicant conveys a response or feedback. So it can be concluded that in the communication process there are elements that support the occurrence of the communication process including sources, communicators, messages, channels and results.

\section{B. Communication Objectives}

Communication is an activity carried out by humans, so that each communication activity can run well and smoothly, then communication activities must have a purpose. According to $\mathrm{H}$.

A. W. Widjaja, in general communication has several objectives, including:

1) So that what we convey can be understood, as communicators we must explain to the communicant as well as possible and thoroughly so that they can follow what we mean.

2) Understanding others, we as leaders of an institution must know the true aspirations of the community about what they want.

3) Moving others to do something. ${ }^{5}$ follows: ${ }^{6}$

Meanwhile, according to Onong U. Effendy, stated the purpose of communication as

\footnotetext{
${ }^{4}$ Ibid, p. 18

${ }^{5} \mathrm{lbid}$, p. 21

${ }^{6}$ Onong U. Effendy, Ilmu, Teori dan Filsafat Komunikasi, (Bandung: PT Citra Aditya Bakti, 2007), p. 55
} 
1) Changing attitude (to change the attitude)

2) Change opinions / opinions / views (to change the opinion)

3) Changing behavior (to change the behavior)

4) Change the society (to change the society)

From some expert opinions above, it can be concluded that the purpose of communication is basically to convey a message or information from the communicator to the communicant so that after getting the message or information the communicant will understand what the communicator wants, be able to change attitudes, opinions and behavior or move the communicant to do something and other goals.

\section{Barriers to Communication}

It is not an easy thing to carry out communication. There are several obstacles that can interfere with the course of the communication. According to David R. Hampton, quoted by Moekijat, classifying communication barriers into: ${ }^{7}$

1) Obstacles to the source, can be caused by the sender conveying the message is not clear so the recipient is hesitant to interpret.

2) Obstacles in delivery, can be caused by messages through intermediaries so that the message conveyed understanding may change.

3) Obstacles to the recipient, can be caused by lack of attention, premature appraisal, more response to traits or behaviors that are not important to the message.

4) Obstacles in feedback, the existence of one-way communication that does not allow for feedback from the recipient.

Meanwhile according to According to William B. Werther and Keith Davis Bariers quoted by Moekijat, obstacles in communication are: ${ }^{8}$

1) Personal hurdles, i.e. disorders that arise because of emotions, values, and human limitations.

2) Physical barriers, namely communication disorders in the environment of communication (for example: the type of sound, air and so on).

3) Semantic barriers, namely communication barriers caused by the understanding of the symbols used.

From the opinions of some of the experts it can be concluded that the obstacles in the implementation of communication are obstacles or obstacles originating from the source, obstacles in the delivery, obstacles in the recipient as well as obstacles in the feedback. These obstacles can be classified as personal, physical and semantic barriers.

\section{Efforts to Overcome Communication Barriers}

There are obstacles in communication there must also be a way out to overcome these obstacles. According to Gitosudarmo and I Nyoman Sudita, to overcome obstacles in communication can be done as follows:?

1) Increase feedback, to find out whether messages or information have been received, understood and implemented or not.

\footnotetext{
${ }^{7}$ Moekijat, Teori Komunikasi, (Bandung: Mandar Maju, 2003), p. 202

8 Ibid, p. 191

${ }^{9}$ Indrito Gito Sudarmo \& I Nyoman Sudita, Perilaku Keorganisasian, (Yogyakarta: BPFE, 2000), p. 216
} 
2) Empathy, delivery of messages tailored to the circumstances of the recipient.

3) Repetition, to guarantee that the message can be received.

4) Using simple language so that everyone can understand the contents of the message conveyed.

5) Determining effective time, the message is delivered when the recipient is ready to receive the message.

6) Listening effectively so that communication can take place properly.

7) 7)Regulate the flow of information, the quality of communication must be regulated, the amount and method of delivery.

8)

From the opinions above, it can be concluded that by always learning to be a good communicator and communicant, always giving feedback on messages received and increasing empathy.

\subsection{Asmaul Husna}

Asmaul Husna is a combination of two words in Arabic that are used for the names of Allah, Asma' according to the language is interpreted by the names, while Al-Husna means good or good. Then after being combined the two words become asmaul husna with the meaning of the nice name.

Asmaul Husna's definition according to the term of Ablus Sunnah wal Jama'ah are the names of Allah who have been attributed by Allah to Himself, both those determined by Allah to Himself in the Qur'an, and those determined by the Prophet without ta'wil (deviation), takyif (asking how), tamtsil (parable), and Tasybih (likeness). This is in accordance with the word of God: "There is notbing like Him, and He is All-Hearing, All-Seeing." (Surat Ash-Syuura: 11).

Among the many names of Allah, only one name becomes His substance, which is the pronunciation of Allah. Which besides everything is noted to him the meanings of nature. Because of that, then the names other than Allah's recitation can be used as information for the death of God.

From this explanation it can be understood that the name of the substance for Allah is the single name, the recitation of Allah which is termed Al-Ismul mufrat, while the other names all contain the notion of explanation for the recitation of Allah.

God introduces Himself to His servants by explaining His proper names with His majesty. The Prophet Muhammad (saas) explained the Asmaul Husna in the hadith narrated by Bukhari: Say the Messenger of Allah: "Allah has ninety-nine names, one hundred and one less, the person who memorized it entered heaven. And God is odd. He likes the odd".

Asmaul Husna is an element that is always present in the daily lives of Muslims. He is always spoken when going to do something or when ending it. Even Asmaul Husna is very famous and looks at the names of people, such as Abdur Rahman, Abdul Wadud, Abdul Ghaffar and so forth. Asma Husnaini is also often said when happy, well-off, and always said after praying. Asmaul Husna is also sung and adored by a group of people at various events. The use of Asmaul Husna like this is something very normal.

\subsection{Asmaul Husna Criteria}

Allah has Asmaul Husna, whom He named Himself by that name, and these names are all Husna (beautiful). As Allah mentions it in the Qur'an: "Only belongs to Allah asmaul busna, so ask. Him 
by mentioning that Asmaul Husna and leave those who stray from the truth in (calling) His names. Later they will get a reply to what they have done." (Al-A'raf: 180).

In this modern age, the lack of knowledge about asmaul husna especially its meaning is the most common problem among muslim society. By learning asmaul husna via traditional methods such as text books and white board, muslims are getting less motivated and have no desire to learn more about Asmaul Husna (Rosmani, 2018). The problem with the Asmaul Husna criteria is that there is a disagreement among scholars. Most scholars believe that it is not permissible to name Allah by names that are not mentioned in the proof of naqli, namely the Qur'an and the hadith, even though the name reflects the perfection of Allah. So don't say "Allah is the Architect of the universe" and don't say "Allah is the general director". Do not say so if it is intended as a name for God, even if it is done to comply with God. But it can be said so in order to explain the tashauf of God for this nature to bring understanding to the listeners.

Thus, the opinion of jumhur ulama above can be understood that this asmaul husna is limited by what has been determined shara', they forbid naming Allah by other than the name set by Allah himself in the Qur'an and by His Messenger in the hadith.

Naming God with names that are not fixed by syara' as Asmaul Husna, such as naming the Father by Christians and naming 'illat al-fa'ilah by philosophers, this is a deviant act, especially the names they give to God is is a heart.

In the Qur'an there are a number of verses that warn against making mistakes in the name or nature of Allah, including sura Al-An'am verse 100: "The Most Holy God and the Most High of the qualities they give". This verse warns against mistakes made by using human languages when making the nature of Allah, especially expressions that are often used to describe human character and behavior.

About the determination of the attributes of perfection for Allah SWT Ibn Qayyim has expressed his opinion in his book "Madarijus saalikin", that the determination of the attributes of perfection for Allah swt in two ways, this method is the method adopted by his teacher Shaykh Ibn Taymiyah, the method is :

First, by way of revelation that came from Allah through the oral Messenger of Allah. The message has come with the determination of the qualities of perfection for Allah in detail in a form that removes things that are still vague.

Secondly, by way of Al-hiss (five senses) that is watching by seeing the signs of creation in nature, then these signs of creation become evidence for the attributes of the Creator. His life, His power, His Knowledge and His will. Then the substance that creates is more entitled to the Most Perfect.

The opinion of Ibn Qayyim above can be understood that the determination of the attributes of perfection for Allah is more general, that is, it can be determined by what has been determined by the Shariah 'and with the five senses. Ibn Qayyim's opinion is different from the opinion of most scholars as mentioned above, where most scholars only limit the determination of the attributes of perfection for Allah with the attributes that have been determined by the sharia 'that is the Qur'an and the hadith. 
The opinion of most of these scholars is in accordance with the opinion of Imam Shafi'i which he expressed in the beginning of the sermon ar-treatise, in which he praised Allah with the nature in accordance with those set by God Almighty and His Messenger.

Where Ash-Shafi'i determines all the names of Allah in accordance with what is appropriate for Allah without tasybih, takyif, takwil and tamtsil, as exemplified by the salaf ulama method. For this reason, he also refers to intellectual information sourced from the Qur'an and Sunnah.

Actually Asmaul Husna is a name that has virtue, and that produces a reward for those who read it. And if the recited Asmaul Husna was read with full awareness and sincerity, then the reader will feel calm and peaceful.

\section{Discussion}

Islamic theology is a central and very definite guide to the life of the Islamic Ummah, because theology is the basis for every charity it does. Only charity based on theology according to Islamic guidance will lead people to a good life and ultimate happiness in the afterlife, because departing from this theology, humans can know the God they worship.

One way or way to know God is to know and understand the names of Allah (Asmaul Husna). Asmaul Husna is the intermediary used by Allah so that people can confer to Him. This is what can be considered a channel through which humans can know God spontaneously. And it is precisely this which can move the way of discovery that is essential and opens up vast realms of spirituality to witness the light of Allah.

Ibn Al-'Arabi views Asmaul Husna as an intermediary between God and nature, namely Asmaul Husna as relationships between relations, namely relations between God and nature, between the One and many. If God were without contact with nature, God did not have names because every name of God is always understood as the relationship between God and nature, which is to meet the needs of nature to God.

In the view of Ibn Al-'Arabi above, it can be understood that the substance of God does not need nature, so from the necessity of God's substance to nature also means the need of God to the names. Only nature needs God, so nature needs the names of God so that it can relate to God.

Another view expressed by Ibn Qayyim in his book Madarijus Saalikin, he argues as his teacher Syaikhul Islam Ibnu Taimiyyah argues, that Asmaul Husna is a substance of God. This contradicts the opinions of some of the Mu'tarilah. Ibn Qayyim presents some of his arguments:

First, that Asmaul Husna is the asthma that Allah attributes to Himself, which shows the attributes of God's perfection. Because Asma is derived from traits, Asma is trait. Because Asma is a trait, it is there to him. And if this asthma is only in the form of lafad without meaning, then it is no longer existent and does not show perfection anymore.

Secondly, if the name of Allah does not include the meaning and nature, then it is not appropriate to say the actions of the Asma to Allah, so do not say Allah Almighty hears, power and others. 
Third, if the name of Allah swt does not show the meanings and attributes, then it is not justified to inform him of the sources of asthma and it is not justified to attribute it to the asthma. Even though there are many Asma sources that Allah has preached in Al-Qu'an.

Fourth, and if the name of Allah swt is not a substance and characteristics, then the Asma is an inanimate object like the other names, so that the name of Allah is the same lafad without differences with what is shown.

From the opinion of Ibn Qayyim above, it can be understood that the Asmaul Husna that Allah attributes to Himself according to Ibn Qayyim's view is God's substance itself. Ibn Qayyim's opinion is different from the opinion of some scholars, they say that Asmaul Husna is a zaidah characteristic that stands on matter, not substance self.

Asy-Syahrastany stated in his book Al milal wan-Nihal, the Mu'tazilah group on this issue had two understandings, some of them argued as Ibn Qayyim's opinion that Asmaul Husna was God's substances themselves, such as the owner or seller of livestock. Some others argue that the names of Asmaul Husna are qualities that are born, like a poet.

The problem of Asmaul Husna about qadim or not is the case of disagreement among scholars. As expressed by the circle of Ablus Sunnah, like Imam Ahmad and others, they stated their denial of the opinion of the Jabmiyyah group who said that Asmaul Husna was a being. The Jahmiyyah group concluded that the names were not named, so the names of Allah SWT were other than Allah SWT, and anything that was not Him or that other than Him meant creatures. The argument they say is that Allah is a creature, and the name Allah is mentioned in words, so the name Allah is also a creature like words. Whereas the reason given by the Ablus Sunnah group is the opposite, namely Allah salam qadim.

When viewed from the arguments put forward by the Jahmiyyah and Ablus Sunnah groups above, this disagreement occurred because there had already been differences of opinion on the issue of the word of Allah swt. According to Ablus Sunnab words of Allah Almighty, so Asmaul Husna is also Qadim. Instead the understanding of the Jahmiyyah group.

\section{Conclusion}

Asmaul Husna are the names of Allah that have been attributed by Allah to Himself, both those that Allah has established for Himself in the Qur'an, and those determined by the Prophet without ta'wil (deviations), takyif (asking how ), tamtsil (parable), and Tasybih (likeness).

There was a difference of opinion among scholars in the determination of Asmaul Husna. The opinion of jumhur ulama that Asmaul Husna is limited by what has been determined by the Shariah. Ibn Qayyim's opinion that the determination of the attributes of perfection for Allah can be determined by what has been determined by the Shariah 'and with the five senses.

Ibn Al-'Arabi views Asmaul Husna as an intermediary between God and nature, namely Asmaul Husna as the relationship between God and nature.

Another view expressed by Ibn Qayyim in his book Madarijus Saalikin, that Asmaul Husna is a substance of God. This contradicts the opinion of some Mu'tazilah groups, that Asmaul Husna is a trait that is born. The opinion of the Jahmiyyah group that says Asmaul Husna is a being challenged by the Ahlus Sunnah group. 


\section{References}

Mahmut Yunus, Kamus Arab-Indonesia, (Jakarta: Mahmut Yunus Wadzuryah).

Muhammad Bin A. W. Al-'Aqil, Manhaj al-Imam asy-Syafi'i fii Itsbaat al-'Aqiidah, Terjemahan, Nabhani Idris. (2006). Manhaj ’Aqidah Imam asy-Syafi'i. Jakarta: Pustaka Imam asy-Syfi’i.

Muhammad Hasbi Ash Shiddieqi. (1999). Ilmu Tauhid. Semarang: Pustaka Rizki Putra.

Bayhaqi, Asma' was Sifat, (Bairut: Darul Kutub Al-'Alamiiah)

Departemen Agama RI. (2004). Al-Qur’an dan Terjemahannya. Bandung: Penerbit Diponegoro. Jefry Lang. (2004). Hatta Al-Malaikah Tas'al. Tjh. Saiful Hadi. Islam di Mata Profesor Matematika. Jakarta: Restu Ilahi.

Muhammad Al-Anwar As-Sanhuti.(2004). Ibnu Qayyim Al-Jauzyyah Siratuhu Manhajuhu wa Araauhufil Ilahiyat, Tjh. M.Romli, Ibnu Qayyim Berbicara Tentang Tuhan. Jakarta: Mustaqiim.

Rosmani, Arifah Fasha \& Zakaria, Mohd. (2018). Asmaul Husna Learning through Gamifications and Adaptation of Signalling Principle. Journal of Physics: Conference Series, 1-Saiful Bahri. (2018). Hadiths About Communication Ethics(Study of Hadiths about Responsibility and Maintaining Information Accuracy). Budapest International Research and CriticsInstitute-Journal (BIRCI-Journal), 265-276.

Sayid Sabiq. (2006). 'Aqidah Islam. Bandung: Diponegoro.

Kautsar Azhari Noer. (1995). Ibnu Al-'Arabi Wahdat al-Wujud dalam Perdebatan. Jakarta: Paramadina. 